\title{
Fertilizer for Maximum Output and Growth of BJRI Tossa Pat-8
}

\author{
Abida Sultana*, Md Tanvir Rahman, Md Abdul Alim, Md Saheb Ali
}

Soil Science Department, Bangladesh Jute Research Institute, Dhaka, Bangladesh

Email address:

oni.abida@gmail.com (A. Sultana)

*Corresponding author

\section{To cite this article:}

Abida Sultana, Md Tanvir Rahman, Md Abdul Alim, Md Saheb Ali. Fertilizer for Maximum Output and Growth of BJRI Tossa Pat-8. American Journal of Bioscience and Bioengineering. Vol. 9, No. 5, 2021, pp. 143-146. doi: 10.11648/j.bio.20210905.13

Received: September 22, 2021; Accepted: October 12, 2021; Published: October 21, 2021

\begin{abstract}
Fertilizing in a balanced way promotes crop quality and soil health as well as crop growth and production. This study was conducted to determine the best approach of fertilization for jute production in Bangladesh in the experimental fields under Bangladesh Jute Research Institute. A randomized block design with three replications was used to set up the experiment, which included ten fertilizer treatments. The treatments were: $T_{1}-$ control (no fertilization), $T_{2^{-}} 50: 10: 30: 20 \mathrm{~kg}$ $\mathrm{N}: \mathrm{P}: \mathrm{K}: \mathrm{S} \mathrm{ha}^{-1}, \mathrm{~T}_{3^{-}}$100:10:30:20 kg N:P:K:S ha ${ }^{-1}, \mathrm{~T}_{4^{-}}$150:10:30:20 kg N:P:K:S ha ${ }^{-1}, \mathrm{~T}_{5^{-}}$100:5:30:20 kg N:P:K:S ha ${ }^{-1}, \mathrm{~T}_{6^{-}}$ 100:15:30:20 kg N:P:K:S ha ${ }^{-1}, T_{7^{-}}$100:10:60:20 kg N:P:K:S ha ${ }^{-1}, T_{8^{-}}$100:10:90:20 kg N:P:K:S ha ${ }^{-1}, T_{9^{-}} 100: 10: 60: 10 \mathrm{~kg}$ $\mathrm{N}: \mathrm{P}: \mathrm{K}: \mathrm{S} \mathrm{ha}^{-1}, \mathrm{~T}_{10^{-}}$100:10:90:30 kg N:P:K:S ha ${ }^{-1}$. The purpose of this study was to determine what nutrition BJRI Tossa pat-8 need for optimal growth and yield. The results indicated significant effect on yield and yield contributing characters over control with different NPK and S levels of BJRI Tossa Pat-8. The highest fibre and stick yield were obtained by the combination dose of $\mathrm{N} 100 \mathrm{Kg} \mathrm{ha}^{-1}$ with 10:60:20 kg P:K:S ha ${ }^{-1}$. The plant height, base diameter also found highest with the same treatment of fertilizer combination. Therefore this combination $\left(\mathrm{T}_{7^{-}}\right.$100:10:60:20 $\mathrm{kg} \mathrm{N}: \mathrm{P}: \mathrm{K}: \mathrm{S}$ ha $\left.{ }^{-1}\right)$ seemed to be optimum for good growth and high potential for BJRI Tossa Pat-8 for fibre production in Bangladesh.
\end{abstract}

Keywords: Fibre Yield, Growth, Nutrient, BJRI Tossa Pat-8

\section{Introduction}

Jute, an important and the largest natural fiber crop belonging to the genus Corchorus, family Tiliaceae, is an eco-friendly and the major cash crop of Bangladesh. Jute fiber is produced mainly from white jute (C. capsularis), and tossa jute $(C$. olitorius). Bangladesh and India produce over $92 \%$ of the total jute fibre of the world. The major jute growing areas in Bangladesh are Faridpur, Jessore, Manikganj, Kishoregan, Mymensingh and Rangpur regions. It is one of the most popular fibre crops in every districts of Bangladesh. Corchorus olitorius is mainly known for its fibre product. Jute is highly responsive to chemical fertilizer and organic manures. Use of chemical fertilizers has positive as well as negative effect on soil microbial population and their activities. Soil organisms act as primary driving agents. The application of essential plant nutrients in optimum quantity and right proportion, through correct method and time of application is the key to increased and sustained crop production [1]. This over-fertilization by farmers, driven by the desire for higher yields, does not always contribute to high yield but it has recently become a common practice for farmers in China nonetheless [2]. Unfortunately, over-fertilization decreases the efficiency of nutrient use and causes a series of economic and environmental problems [3]. However, balanced mineral fertilizer inputs have played an important role in increasing the rice and oilseed rape yields. Therefore, it is very important to apply fertilizers in an efficient way to minimize loss and to improve the nutrient use efficiency [4]. Mineral nutrition of plants is important for controlling physiological and biochemical processes of plants. Its deficiency may lead to changes in these processes and disturbed plant growth and yield [5]. Nitrogen plays a key role in agriculture by increasing of crop yield [6]. Optimum, rate of $\mathrm{N}$ increases photosynthetic processes, leaf area production, leaf area duration as well as net assimilation rate [7]. Phosphorus deficiency is invariably a common crop growth and yield-limiting factor in unfertilized soils, especially in soils high in Calcium carbonate, which reduces solubility [8]. Potassium plays a vital role in the 
plants especially in cell metabolism, activate enzyme activity and enhanced the plant growth and crop quality [9-11]. Sulfur is an essential nutrient for plant growth and metabolism. Responses in crop growth and yield to the addition of $\mathrm{S}$ have been reported [12]. Therefore, present study is aimed to determine the nutritional requirement of the BJRI Tossa pat- 8 for fibre production.

\section{Materials and Methods}

The experiment was conducted in the experimental field under Bangladesh Jute Research Institute. The experiment was laid out in randomized complete block design with three replications. A total 10 treatment combinations along with a control were distributed randomly in each plot as one replication (Table 1). The dimension of unit plots was $3.1 \mathrm{~m}$ $\times 3.1 \mathrm{~m}$ having $1 \mathrm{~m}$ space between the plots, blocks and around the field. There was $20 \mathrm{~cm}$ deep drain around each block and plot. Each replication was divided into 10 unit plots and the total land required of $13.3 \mathrm{~m} \times 42 \mathrm{~m}$. At the beginning of the experiment, the land was well prepared and fertilizers were applied as per treatment.

Table 1. Treatment combinations (NPKS in $\mathrm{Kg} / \mathrm{ha}$ ).

\begin{tabular}{ll}
\hline Tr. N-P-K-S- kg/ha & Tr. N-P-K-S kg/ha \\
\hline $\mathrm{T}_{1}: 00-00-00-00$ & $\mathrm{~T}_{6}: 100-15-30-20$ \\
$\mathrm{~T}_{2}: 50-10-30-20$ & $\mathrm{~T}_{7}: 100-10-60-20$ \\
$\mathrm{~T}_{3}: 100-10-30-20$ & $\mathrm{~T}_{8}: 100-10-90-20$ \\
$\mathrm{~T}_{4}: 150-10-30-20$ & $\mathrm{~T}_{9}: 100-10-60-10$ \\
$\mathrm{~T}_{5:}: 100-5-30-20$ & $\mathrm{~T}_{10}: 100-10-90-30$ \\
\hline
\end{tabular}

Required amounts of N, P, K, S fertilizers were applied in the form of urea, TSP, MoP and gypsum. Half of Urea was applied at sowing and the rest half was top dressed at 45 days after sowing while all other fertilizers were applied at the time of sowing. Jute seeds were broadcasted at the rate of $8 \mathrm{~kg} / \mathrm{ha}$. All cultural operations were done as and when necessary. The crop was harvested when $80 \%$ of the plants showed the sign of maturity. After shedding of leaves, the bundles were steeped plot-wise in pond water for 15-20 days for retting and fiber was extracted. At harvesting time, six plants were selected at random from each plot and tagged in the field to note plant height $(\mathrm{PH})$, base diameter (BD), green yield (GY), fiber yield (FY) and stick yield (SY). Statistical analysis was done [13].

\section{Results and Discussion}

To introduce combination treatments, the experiment used four nitrogen levels $(0,50,100$, and $150 \mathrm{~kg} / \mathrm{ha})$ in conjunction with other nutrients. Plant growth and yield were altered by nitrogen levels compared to the contro. Nitrogen (a) $100 \mathrm{Kg} /$ ha treatment $\left(\mathrm{T}_{7}\right)$ produced significant highest fibre yield. But highest dose of $\mathrm{N} 150 \mathrm{Kg} / \mathrm{ha}$ showed significantly lower yield than the dose N $100 \mathrm{~kg} /$ ha. The growth indicator i.e. plant height and base diameter found significantly highest by $\mathrm{N} 100 \mathrm{Kg} /$ ha and treatment $\mathrm{T}_{4}$ where $\mathrm{N} 150 \mathrm{Kg} /$ ha used showed statistically lower base diameter to treatment $\mathrm{T}_{7}$ where used $\mathrm{N} 100 \mathrm{Kg} /$ ha. From the results, it was observed that $100 \mathrm{~kg} \mathrm{~N} /$ ha may be an adequate amount to produce BJRI Tossa Pat- 8 .

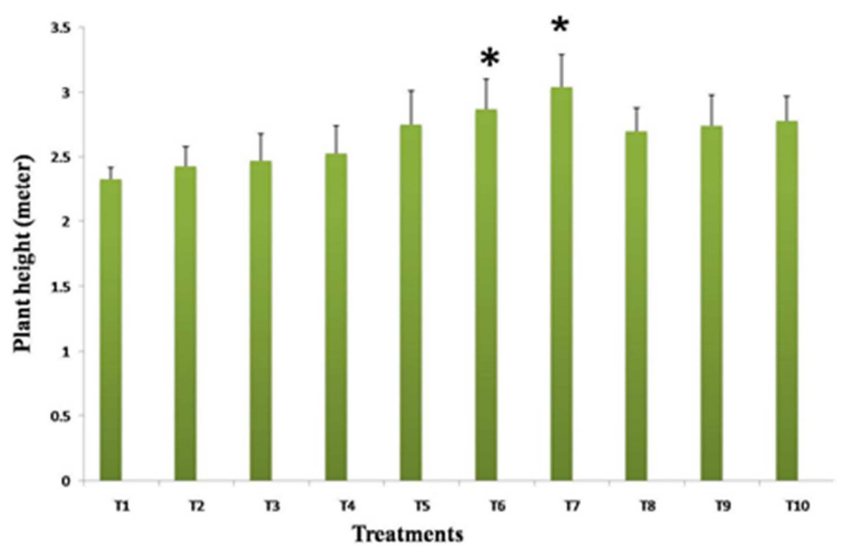

Figure 1. Plant height of newly released variety BJRI tossa pat-8 using different chemical fertilizer treatments. Each datum was calculated from three independent experiments. The results are expressed as the mean $\pm S . E$. M. ${ }^{*} p<0.05$ significance by the Student's t-test.

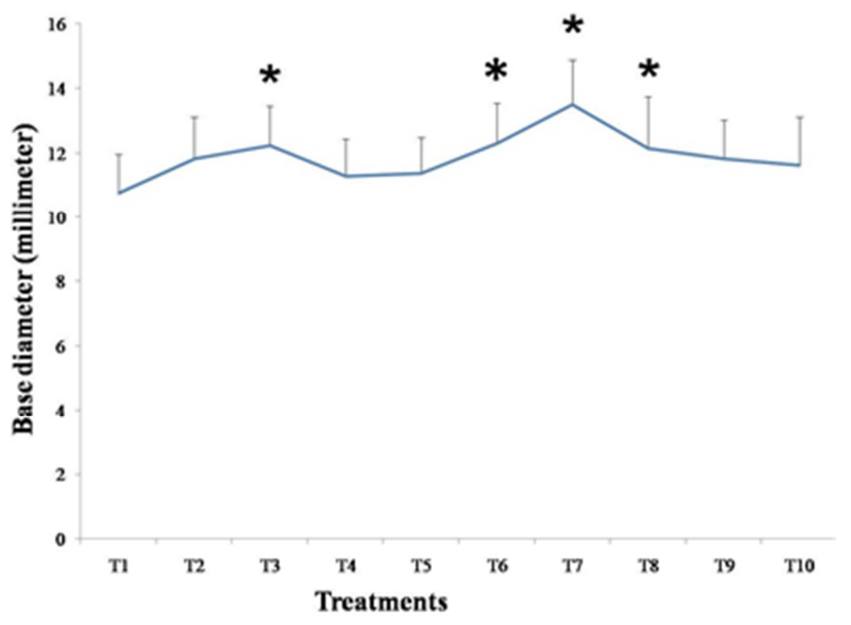

Figure 2. Base diameter of newly released variety BJRI tossa pat-8 using different chemical fertilizer treatments. Each datum was calculated from three independent experiments. The results are expressed as the mean $\pm S . E$. M. ${ }^{*} p<0.05$ significance by the Student's t-test.

The effects of varying phosphorus levels on BJRI Tossa Pat- 8 growth and yield metrics were investigated. The dose of $\mathrm{P} 10 \mathrm{Kg} / \mathrm{ha}$ contributed maximum yield of fibre. Results also explored that the longest plant and base diameter were found significantly higher with $10 \mathrm{~kg} \mathrm{P} /$ ha (Figures $1 \& 2$ ).

Potassium was applied at four different rates: 0, 30, 60, and $90 \mathrm{~kg} / \mathrm{ha}$. The rate $60 \mathrm{~kg} \mathrm{~K} / \mathrm{ha}$ gave the statistically significant plant height, base diameter and fibre yield. But the supreme rate of $\mathrm{K} 90 \mathrm{~kg} / \mathrm{ha}$ yielded lower fibre yield compare to $\mathrm{K} 60 \mathrm{~kg} / \mathrm{ha}$. Study noticed that BJRI Tossa Pat- 8 , needs $\mathrm{K} 60 \mathrm{Kg} /$ ha to produce maximum yield. Highest plant height, base diameter, Green yield with and without leaf, fibre yield and stick yield were observed with $20 \mathrm{~kg} \mathrm{~S} / \mathrm{ha}$ (Figures 1-5). Results showed that combined dose of NPK and $\mathrm{S} 100-10-60-20 \mathrm{Kg} / \mathrm{ha}$ may be a suitable combination for the cultivation of BJRI Tossa Pat- 8 . These findings are strongly supported by the previous research results [14-23]. 

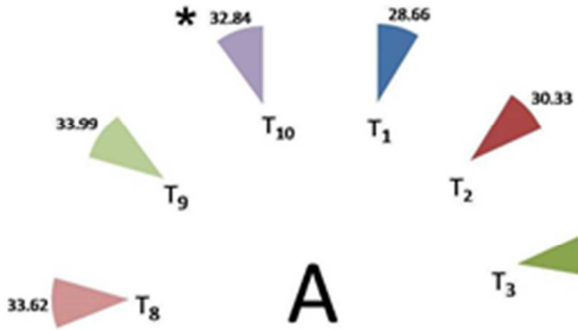

A
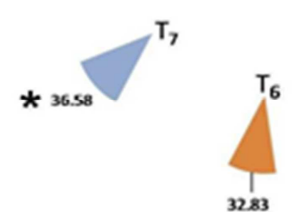
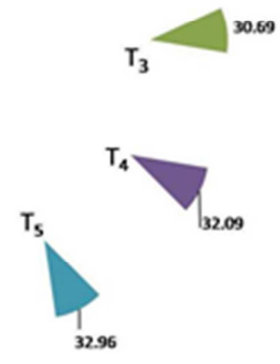
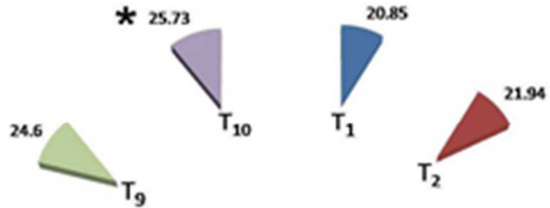

B
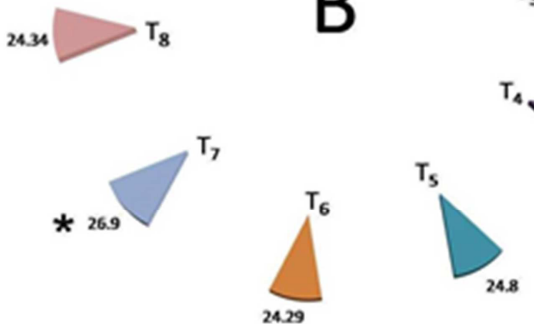

Figure 3. Green yield with (A) and without (B) leaves of newly released variety BJRI tossa pat-8 using different chemical fertilizer treatments. Each datum was calculated from three independent experiments. The results are expressed as the mean $\pm S . E$. M. ${ }^{*} p<0.05$ significance by the Student's $t$-test.

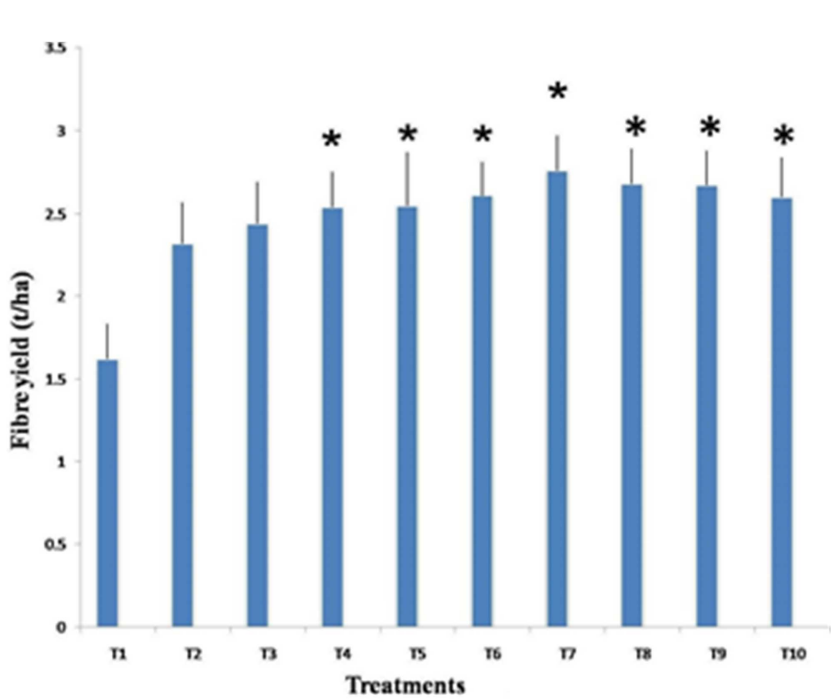

Figure 4. Fibre yield of newly released variety BJRI tossa pat-8 using different chemical fertilizer treatments. Each datum was calculated from three independent experiments. The results are expressed as the mean $\pm S$. E. $M .{ }^{*} p<0.05$ significance by the Student's t-test.

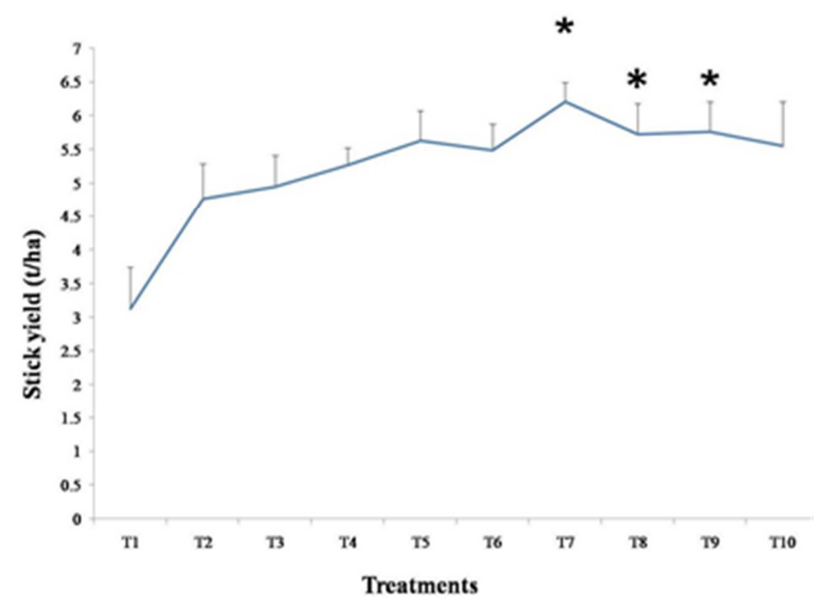

Figure 5. Stick yield of newly released variety BJRI tossa pat-8 using different chemical fertilizer treatments. Each datum was calculated from three independent experiments. The results are expressed as the mean $\pm S$. E. M. ${ }^{*} p<0.05$ significance by the Student's t-test.

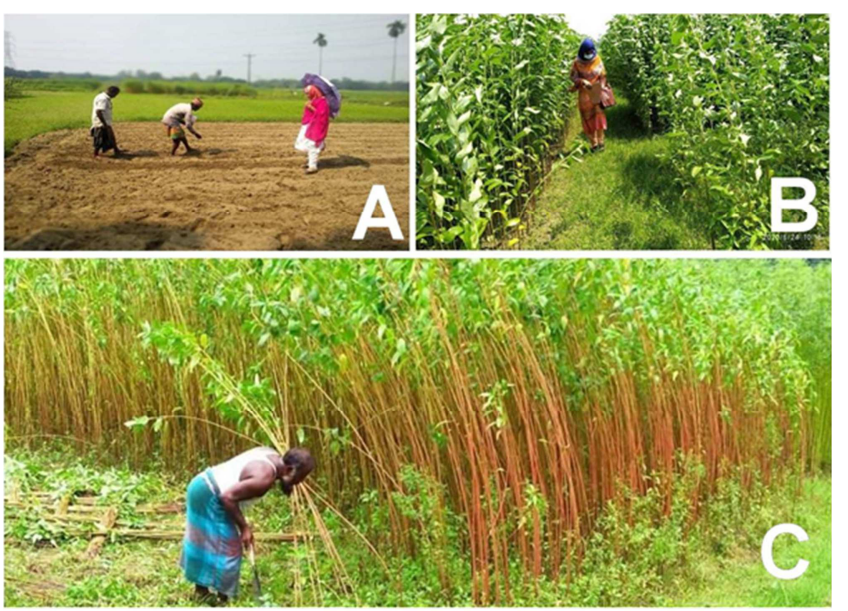

Figure 6. Intensive supervision signifying in experimental field for good agricultural practices (A) Seed sowing (B) Experimental plots (C) Harvesting.

\section{Conclusion}

The use of combined chemical fertilizers had a considerable favorable impact on all yield contributing metrics as well as yield.. Finally, we can conclude that combined dose of NPK and $\mathrm{S} 100-10-60-20 \mathrm{~kg} / \mathrm{ha}$ is appropriate for the cultivation of BJRI Tossa Pat-8. The study evolved a technology which ultimately recommendation of fertilizer (NPK \& S 100-10-60$20 \mathrm{Kg} / \mathrm{ha}$ ) for BJRI Tossa Pat-8.

\section{Conflict of Interest}

The authors declare no conflict of interest exists.

\section{References}

[1] Cisse, L. and Ammr, B. 2000. The importance of phosphatic fertilizer for increased crop production developing countries. In: Proceedings of the AFA $6^{\text {th }}$ International Annual Conference, 31 January- 2 February, 2000, Cairo, Egypt. 
[2] Xu, X., Liu, X., He, P., Johnston, A. M., Zhao, S. and Qiu, S. 2015. Yield Gap, Indigenous Nutrient Supply and Nutrient Use Efficiency for Maize in China. PLoS ONE 10 (10): e0140767.

[3] Ju, X., Kou, C., Zhang, F. \& Christie, P. 2006. Nitrogen balance and groundwater nitrate contamination: Comparison among three intensive cropping systems on the North China Plain. Environ Pollut 143, 117-125.

[4] Li, X., Lu, J., Wu, L. \& Chen, F. 2009. The difference of potassium dynamics between yellowish red soil and yellow cinnamon soil under rapeseed (Brassica napus L.)-rice (Oryza sativa L.) rotation. Plant Soil 320, 141-151.

[5] Warington, K. 1923. The effect of boric acid and borax on the broad bean and certain other plants. Ann. Bot. 37: 629-672.

[6] Massignam, A. M., S. C. Chapman, G. L. Hammer and S. Fukai, 2009. Physiological determinants of maize and sunflower achene yield as affected by nitrogen supply. Field Crops Research, 113: 256-267.

[7] Ahmad, S., R. Ahmad, M. Y. Ashraf, M. Ashraf and E. A. Waraich, 2009. Sunflower (Helianthus annuusL.) response to drought stress at germination and seedling growth stages. Pak. J. Botany, 41 (2): 647-654.

[8] Ibrikci, H., J. Ryan, A. C. Ulger, G. Buyuk, B. Cakir, K. Korkmaz, E. Karnez, G. Ozgenturk and O. Konuskan. 2005. Maintenance of $\mathrm{P}$ fertilizer and residual $\mathrm{P}$ effect on corn production. Nigerian Journal of Soil Science, 2: 1279-286.

[9] Birch, C. J., McLean, G. and Sawers, A. 2008. Analysis of high yielding maize production-a study based on a commercial crop. Australian J of Exper Agri 48 (3): 296.

[10] Zia, H., Kubar K. A, Rajpar, I. Shamsuddin, T., Shah, A. N. Shah, J. A. and Maitlo A. A. 2014. Evaluating potassium-useefficiency of five cotton genotypes of Pakistan. Pak J of Bot 46 (4): 1237-1242.

[11] Haji, A, Bu, M. A. A., Ahmad, R., Iqbal J., Maqbool, M. M., Ali A., Ishaque, M. and Hussain, S. 2012. Nutritional and Physiological Significance of Potassium Application in Maize Hybrid Crop Production. Pak J of Nutri 11 (2): 187- 202.

[12] Zhao, F. J., Hawkesford, M. J., and McGrath, S. P. 1999: Sulphur assimilation and effects on yield and quality of wheat. J. Cereal Sci., 30, 1-17.

[13] Gomez, K. A. and Gomez, A. A. (1984). Statistical procedure for Agricultural Research. Second edn. John Wiley and Sons. Inc. New York. Pp. 304-307.

[14] Ali, M. S., Hoque, M. M., Gani, M. N. and Islam, M. M. (2017). Variation in Inorganic Fertilizer Is an Important Regulator of Yield Potential in BJRI Mesta-3. American Journal of Environmental Engineering and Science, 4 (6): 7884.

[15] Ali, M. S., Gani, M. N. and Islam, M. M. (2017). Nutrient Management on Growth and Yield of BJRI Tossa Pat 6. Nutr Food Technol Open Access 3 (3): doihttp://dx.doi.org/10.16966/2470-6086.147.

[16] Ali, M. S., Gani, M. N. and Islam, M. M. (2017). Efficiency of BJRI Kenaf-4 Yield under Different Fertilizer Levels. American Journal of Agriculture and Forestry, 5 (5): 145-149. doi: 10.11648/j.ajaf.20170505.12.

[17] Ali, M. S., Hossen, M., Ahmed, B., Gani, M. N. and Islam, M. M. (2017). Jute Seed Yield Response to Irrigation and Nitrogen Fertilization in Field-Grown Environment. American Journal of Agricultural Science, 4 (6): 149-153.

[18] Gani, M. N., Ali, M. S. and Islam, M. M. (2017). Nutrient Requirement of NPK\&S on Advance Capsularis Breeding Line BJC-5105. International Journal of Agricultural and Biosystems Engineering, 2 (5): 44-47.

[19] Islam, M. M. and Rahman, M. M. (2008). In: Hand book on agricultural Technologies of Jute, Kenaf and Mesta crops. Bangladesh Jute Research Institute, Manikmia Avenue, Dhaka-1207, Bangladesh.

[20] Alam, A. K. M. M., Khandker, S., Gani, M. N., and Ahmed S. A. (2000). Uptake addition and balance of nutrients under integrated fertilizer management in jute based cropping patterns. B. J. Sci. and Tech., 2 (2): 147-153.

[21] Sarker, A. K. and Bandopaddhay, P. K. (2000). Effect of potassium, boron and crop age on the yield and quality of white jute (Corchoruscapsularis). Indian Agr., 26: 212-216.

[22] Das, K., Guha, B. and Pathak, D. (1996). Response of Capsularis to potassium fertilization. Ann. Agril. Res., 17 (2): 188-189.

[23] Sarkar, S. K., Ghosh, R. K., Sounda, G., Maitra, S., Rux, D. K. and Ghosh, K. (1997). Effect of levels of nitrogen, potassium and soil moisture tension on growth, nutrient uptake and water use efficiency of jute. J Interacademia, 1 (3): 183-188. 